\title{
Cost-utility analysis of tuberculosis patients with directly observed treatment and self-administered treatment in an army hospital, Indonesia
}

Santi Purna Sari ${ }^{1}$, Eriska Dara Funna ${ }^{1 *}$, Renni Septini²

${ }^{1}$ Faculty of Pharmacy, Universitas Indonesia, Depok, Indonesia 2Pharmacy Installation of Gatot Soebroto Army Hospital, Center Jakarta, Indonesia

*Corresponding author:

Eriska Dara Funna

Eriska.dara@alumni.ui.ac.id

\section{KEYWORDS:}

Cost-utility analysis;

Tuberculosis; Directly observed treatment; Self-administered treatment

\begin{abstract}
Tuberculosis recorded as the $9^{\text {th }}$ cause of death worldwide and Indonesia becomes the $2^{\text {nd }}$ country with the highest tuberculosis incidence in the world. The previous study showed that tuberculosis can affect the patients' quality of life and high level of expenditures, so a study is needed to link both of them. In this study, a cost-utility analysis was conducted to see how the DOT (Directly Observed Treatment) and SAT (Self-Administered Treatment) influence the patient's quality of life and how much cost for each method. This study used a cross-sectional design with primary data and secondary data collection. The subjects were tuberculosis category I patients aged 18 years and over at Gatot Soebroto Army Hospital. Utilities were obtained with the help of the EQ-5D-5L questionnaire and the costs used were viewed from a social perspective with the components of direct medical costs, direct non-medical costs, and indirect costs. The results obtained in this study was the utility value of 0.718 with total expenses 5.499.656,00 IDR in the DOT group $(\mathrm{n}=12)$ and the utility value of 0.912 with the total expenses 5.804.887,00 IDR in the SAT group $(\mathrm{n}=30)$. Based on these values, the average cost-utility ratio in the DOT group was 7.659.688,02 IDR, in the SAT group was 6.365.007,67 IDR, and an incremental cost-utility ratio was $1.573 .355,67 \mathrm{IDR} /$ utility. The results showed that both methods can be selected according to the available resources, especially funds.
\end{abstract}

\section{INTRODUCTION}

Tuberculosis (TB) recorded as the ninth cause of death worldwide with 10.4 million incidences and 1.7 million deaths in $2016^{(1)}$. Indonesia is the second country with the highest incidence of TB in the world and the incidence rate of 391/ 100,000 population. Indonesia is on the list of 30 countries with the highest TB burden in the world for TB cases, TB-HIV, and MDR-TB ${ }^{(1)}$. WHO (World Health Organization) has been trying to control TB through the End TB Strategy program since 2014. This program is a long-term (2016-2035) to end cases of TB epidemic in the world with a target of reducing the number of deaths due to TB by $95 \%$ and decreasing rates the incidence of TB by $90 \%$ in 2035 compared to $2015^{1}$. In carrying out the program, WHO implemented the 
DOTS (Directly Observed Treatment, ShortCourse) strategy which was recommended since $1995^{2}$. The implementation of DOTS depends on five key components, there are political commitment and funding, guaranteed diagnosis, DOT (Directly Observed Treatment), availability of drugs, monitoring and reporting ${ }^{3}$.

DOT is a direct observation of TB patients undergoing therapy. Observers can come from health workers, families, and social community. The presence of observers is expected to help the improvement of patient compliance compared to unattended therapy or SAT (Self-Administered Treatment). Based on the study, TB patients who were not observed had a risk of 3.636 times for irregular treatment compared with TB patients who were observed ${ }^{4}$. The form of patient compliance also has a close relationship with quality of life because both can provide information about the success of treatment, disease management, and optimal health policy-making 5 .

TB can affect a person's quality of life, both physically, psychologically, socially and his ability to make a living ${ }^{6}$. Based on studies in the UK, TB patients experience a significant decrease in quality of life due to health changes at the time of diagnosis and still have a score below normal after 2 months of treatment ${ }^{7}$. Based on research in Pakistan, TB patients who received therapy for 4-6 months had better mental health and after 7-9 months the patients had better physical health ${ }^{8}$. However, based on a statistical test, there were no significant differences between the quality of life of patients with the DOT and SAT method ${ }^{8}$. After that, based on the Cochrane Database System Review in 2015, the data showed that DOT did not provide a solution to poor adherence in TB treatment ${ }^{9}$.

TB treatment not only requires the right method based on the results obtained but also has to consider the costs incurred because the patient must undergo long treatment. Besides, the incidence of $\mathrm{TB}$ also causes a high economic burden on the country and is estimated to reach the US \$ 6.9 billion $^{10}$. Research on the effect of DOT and SAT methods on medical expenses has also been widely carried out. Based on research in Brazil, DOT has an average cost of US \$ 336 for patients and the US \$ 726 for healthcare providers, while SAT has an average expenditure of US \$ 194 for patients and the US \$ 189 for health care providers ${ }^{11}$. Based on research in Thailand, DOT conducted by families has an average cost of US \$ 20 while the SAT is the US $\$ 29^{12}$.

Based on the high incidence of TB in Indonesia, direct supervision is needed to help the successful treatment of TB patients. Comparison between DOT and SAT method can be seen based on the quality of life and the number of costs that must be incurred. In pharmacoeconomic, the relationship of quality of life with medical cost can be seen through a costutility analysis. The study was conducted at the Gatot Soebroto Army Hospital, where cases of pulmonary tuberculosis were included in the list of the 3 most cases that occurred in $2012^{13}$.

\section{MATERIALS AND METHODS}

\subsection{Sampling}

The population in this study were systematically selected from the registration book in the Pulmonary Department of Gatot Soebroto Army Hospital. The inclusion criteria were category I TB patients with18 years of age and above. The exclusion criteria were patients with TB-HIV, first-line drug TB resistance, incomplete medical record data, and patients who are not willing to be interviewed. The total number of TB cases was recorded from January until April 2018. Based on the registration book, there were 263 patients undergoing treatment at the Pulmonary Department of Gatot Soebroto Army Hospital and among those are 206 patients have TB illness. The category I TB patients was 124 patients and only 42 patients willing to be interviewed.

\subsection{Instruments and measures}

Data were obtained from primary and secondary data collection. Primary data was obtained from eligible patients in a face-to-face interview collected at one time which responses were captured using an adapted and standardized questionnaire. Patients were separated into two groups, namely the DOT method and the SAT method based on their family members role during the treatment. Patients were interviewed in the waiting room during their visit to the Pulmonary Department at Gatot Soebroto Army Hospital. The indicators for cost are direct medical costs, direct non-medical costs, and indirect costs to patients before and during diagnosis. The indicators for quality of life was obtained from the EQ-5D-5L questionnaire ${ }^{14}$. 
Table 1. Characteristics of Patients

\begin{tabular}{|c|c|c|c|c|}
\hline \multirow[t]{2}{*}{ Characteristic } & $\begin{array}{c}\text { DOT } \\
(n=12)\end{array}$ & $\begin{array}{c}\text { SAT } \\
(n=30)\end{array}$ & $\begin{array}{c}\text { Total } \\
(n=42)\end{array}$ & $\bar{p}$ \\
\hline & $n(\%)$ & $n(\%)$ & $n(\%)$ & \\
\hline Domicile & & & & $0.755^{a}$ \\
\hline Central Jakarta & $3(25.00)$ & $13(43.30)$ & $16(38.10)$ & \\
\hline North Jakarta & $2(16.70)$ & $2(6.70)$ & $4(9.50)$ & \\
\hline East Jakarta & $3(25.00)$ & $4(13.30)$ & $7(16.70)$ & \\
\hline West Jakarta & $0(0.00)$ & $1(3.30)$ & $1(2.40)$ & \\
\hline South Jakarta & $1(8.30)$ & $1(3.30)$ & $2(4.80)$ & \\
\hline Lebak & $1(8.30)$ & $1(3.30)$ & $2(4.80)$ & \\
\hline Bogor & $1(8.30)$ & $3(10.00)$ & $4(9.50)$ & \\
\hline Depok & $0(0.00)$ & $2(6.70)$ & $3(7.10)$ & \\
\hline Bekasi & $0(0.00)$ & $2(10.00)$ & $2(4.80)$ & \\
\hline Indramayu & $0(0.00)$ & $1(3.30)$ & $1(2.40)$ & \\
\hline Total & $12(100.00)$ & $30(100.00)$ & $42(100.00)$ & \\
\hline Employment status & & & & $0.659^{a}$ \\
\hline Private sector & $3(33.30)$ & $5(16.70)$ & $8(19.00)$ & \\
\hline Government sector & $1(8.30)$ & $4(13.30)$ & $5(11.90)$ & \\
\hline Enterpreneur & $1(8.30)$ & $4(13.30)$ & $5(11.90)$ & \\
\hline TNI/Polri & $0(0.00)$ & $2(6.70)$ & $2(4.80)$ & \\
\hline Unemployed & $7(58.30)$ & $15(50.00)$ & $22(52.40)$ & \\
\hline Total & $12(100.00)$ & $30(100.00)$ & $42(100.00)$ & \\
\hline Type of TB & & & & $0.341^{\mathrm{a}}$ \\
\hline Pulmonary smear-positive & $6(50.00)$ & $8(26.70)$ & $14(33.30)$ & \\
\hline Pulmonary smear-negative & $2(16.70)$ & $8(2.70)$ & $10(23.80)$ & \\
\hline Extra-pulmonary & $4(33.30)$ & $14(46.70)$ & $18(42.90)$ & \\
\hline Total & $12(100.00)$ & $30(100.00)$ & $42(100.00)$ & \\
\hline The phase of TB Treatment & & & & $0.591^{\mathrm{a}}$ \\
\hline Initial phase & $7(58.30)$ & $13(43.30)$ & $20(47.60)$ & \\
\hline Continuation phase & $5(41.70)$ & $17(56.70)$ & $22(52.40)$ & \\
\hline Total & $12(100.00)$ & $30(100.00)$ & $42(100.00)$ & \\
\hline
\end{tabular}

$\mathrm{a}=$ significance test with Chi-Square

\subsection{Data analysis}

Data were entered using the Statistical Package for Social Sciences (SPSS) v. 25.0 (licence No. f939dfccd193a642d362) and Microsoft Excel 2016. Utility value was obtained from the Indonesian EQ-5D-5L value set research on $2017^{15}$.

\subsection{Ethical considerations}

This study was ethically approved by the Health Research Ethics Committee, Faculty of Medicine, Universitas Indonesia-Cipto Mangunkusumo Hospital (Protocol Number: 18-03-0221). Informed consent was obtained by handwritten.

\section{RESULTS AND DISCUSSION}

\subsection{Characteristics of patients}

The sample in this study was 42 samples which 30 samples entered the SAT group and 12 samples entered the DOT group. Patient characteristics data were analyzed descriptively to see a description of the sample frequency distribution in tuberculosis patients. The test results can be seen in Table 1. Based on statistical tests with Chi-Square, all patient characteristics data have $p>0.05$ which means there is no significant difference for each group.

Based on the place of residence, most of the research subjects lived in Central Jakarta $(38.10 \%)$. This can be influenced by the rules of JKN system set by the government, which for the first time each participant will be registered at a first level health facility established by the local BPJS Health District/City (Gatot Soebroto Hospital located in Senen, Central Jakarta) and can choose their health facilities after 3 (three) months ${ }^{16}$.

Based on work, the research subjects were dominated by unemployed $(52.40 \%)$. Some of them already resigned from their job caused by TB disease, still a student, or just babysitting at the house. Actually, work has a relationship with the incidence of tuberculosis, where patients who work have a higher risk of exposure to Mycobacterium tuberculosis, especially patients with the type of menial work. Besides, work determines the amount of income and affects socio-economic conditions, such as the fulfilment of nutrition, adequate housing, and access to existing health services ${ }^{17}$. 
Table 2. Cost for TB Treatment

\begin{tabular}{|c|c|c|c|}
\hline Cost Type & $\begin{array}{l}\text { DOT (IDR) } \\
\text { (Min-Max) }\end{array}$ & $\begin{array}{l}\text { SAT (IDR) } \\
\text { (Min-Max) }\end{array}$ & $p$ \\
\hline \multicolumn{4}{|l|}{ Direct Medical Cost } \\
\hline Anti-TB drugs & $\begin{array}{c}95.475,00^{\mathbf{b}} \\
(0,00-721.260,00)\end{array}$ & $\begin{array}{c}212.257,50^{\mathbf{b}} \\
(0,00-733.425,00)\end{array}$ & $0.863^{\mathrm{a}}$ \\
\hline Another drug (except anti-TB drugs) & $\begin{array}{c}157.670,50^{\mathbf{b}} \\
(0,00-1.300 .085,00)\end{array}$ & $\begin{array}{c}116.602,00^{\mathbf{b}} \\
(5.310,00-448.143,00)\end{array}$ & $0.330^{\mathrm{a}}$ \\
\hline Professional health worker & $\begin{array}{c}2.001 .666,67^{\mathrm{c}} \\
(450.000,00-3.600 .000,00)\end{array}$ & $\begin{array}{c}1.753 .166,67^{\mathrm{c}} \\
(450.000,00-3.600 .000,00)\end{array}$ & $0.512^{\mathrm{a}}$ \\
\hline Smear sputum test & $\begin{array}{c}707.500,00^{\mathrm{c}} \\
(0,00-2.000 .000,00)\end{array}$ & $\begin{array}{c}420.000,00^{\mathbf{b}} \\
(0,00-2.600 .000,00)\end{array}$ & $0.205^{\mathrm{a}}$ \\
\hline Radiology and pathology anatomy test & $\begin{array}{c}275.000,00^{\mathbf{b}} \\
(125.000,00-5.885 .000,00)\end{array}$ & $\begin{array}{c}150.000,00^{\mathbf{b}} \\
(0,00-2.444 .000,00)\end{array}$ & $0.155^{\mathrm{a}}$ \\
\hline $\begin{array}{l}\text { Laboratorium test (except for smear } \\
\text { sputum test) }\end{array}$ & $\begin{array}{c}597.500,00^{\mathrm{c}} \\
(0,00-1.730 .000,00)\end{array}$ & $\begin{array}{c}455.000,00^{\mathbf{b}} \\
(0,00-2.419 .000,00)\end{array}$ & $0.531^{\mathrm{a}}$ \\
\hline Administrative & $\begin{array}{c}112.500,00^{\mathrm{c}} \\
(30.000,00-260.000,00)\end{array}$ & $\begin{array}{c}101.666,67^{\mathrm{c}} \\
(20.000,00-240.000,00)\end{array}$ & $0.746^{\mathrm{a}}$ \\
\hline \multicolumn{4}{|l|}{ Direct Non Medical Cost } \\
\hline Food & $\begin{array}{c}0,00^{\mathbf{b}} \\
(21.000,00-2.080 .000,00)\end{array}$ & $\begin{array}{c}102.500,00^{\mathbf{b}} \\
(0,00-5.000 .000,00)\end{array}$ & $0.165^{\mathrm{a}}$ \\
\hline Transportation & $\begin{array}{c}340.500,00^{\mathbf{b}} \\
(0,00-520.000,00)\end{array}$ & $\begin{array}{c}316.000,00^{\mathbf{b}} \\
(0,00-5.000 .000,00)\end{array}$ & $0.477^{\mathrm{a}}$ \\
\hline Additional cost & $\begin{array}{c}463.000,00^{\mathbf{b}} \\
(0,00-4.000 .000,00)\end{array}$ & $\begin{array}{c}267.500,00^{\mathbf{b}} \\
(0,00-6.000 .000,00)\end{array}$ & $0.746^{\mathrm{a}}$ \\
\hline $\begin{array}{l}\text { Indirect Cost } \\
\text { Opportunity cost }\end{array}$ & $\begin{array}{c}0,00^{\mathbf{b}} \\
(0,00-42.000 .000,00)\end{array}$ & $\begin{array}{c}0,00^{\mathbf{b}} \\
(0,00-9.000 .000,00)\end{array}$ & $0.351^{\mathrm{a}}$ \\
\hline Total & $5.499 .656,00^{b}$ & $5.804 .887,00^{b}$ & \\
\hline
\end{tabular}

$\mathrm{a}=$ significance test with Mann-Whitney; $\mathrm{b}=$ median; $\mathrm{c}=$ mean

Based on the type of tuberculosis, the subjects in this study mostly suffered from extrapulmonary $(42.90 \%)$, followed by pulmonary smear-positive $(33.30 \%)$, and pulmonary smearnegative $(23.80 \%)$. Meanwhile, $52.40 \%$ were undergoing continuation phase treatment and $47.60 \%$ were undergoing initial phase treatment. As a third level PPK, the services contained in the Gatot Soebroto Army Hospital are complete, so many referral patients who check themselves into the hospital are an attempt to establish a diagnosis of extrapulmonary TB patients who usually require a radiological and histopathological check.

\subsection{Costs}

Cost analysis is carried out to determine the total cost component of the treatment of tuberculosis patients. The cost perspective used is the social perspective with the cost component as in Table 2. Costs include direct medical costs, direct nonmedical costs, and indirect costs. Direct medical costs are medical expenses incurred by the hospital, including the cost of anti-tuberculosis drugs (ATD), the cost of other drugs to treat side effects of ATD or to reduce symptoms of tuberculosis, the cost of health care services, costs for laboratory, costs for radiology and anatomical pathology, costs for laboratory (other than sputum examination), and costs for administrations. Direct nonmedical costs are costs that patients directly spend not for medical purposes, such as transportation costs, meal costs, and additional costs that must be incurred during illness. Indirect costs are costs that are lost due to illness or opportunity costs.

Each component of costs was tested statistically using the Mann-Whitney test and the result of the significance value was $\mathrm{p}>0.05$. These results illustrate that there is no significant difference between the components of each cost in the DOT and SAT methods. Furthermore, the total medical expenses are 5,499,656.00 IDR for the DOT method and 5,804,887.00 IDR for the SAT method. The total cost of treatment will be used to calculate the cost-utility ratio and the incremental cost-utility ratio.

Direct medical costs have a variation cost due to many things, except for administrative cost and professional health worker cost. This is happened due to the constant cost for both, there is 10.000,00 IDR per visit for hospital fee administration and 150,000.00 IDR per visit for consulting a specialist. 
Table 3. Comparison Health-Related Quality of Life Value on DOT vs SAT Group

\begin{tabular}{|c|c|c|c|c|}
\hline Group & Utility & $p$ & VAS & $p$ \\
\hline $\begin{array}{l}\text { DOT } \\
\text { SAT }\end{array}$ & $\begin{array}{l}0.718^{\mathrm{c}} \\
0.912^{\mathrm{b}}\end{array}$ & $0.063^{\mathrm{a}}$ & $\begin{array}{l}72.92^{\mathrm{c}} \\
80.00^{\mathrm{b}}\end{array}$ & $0.375^{\mathrm{a}}$ \\
\hline
\end{tabular}

$\mathrm{a}=$ significance test with Mann-Whitney; $\mathrm{b}=$ median; $\mathrm{c}=$ mean

Variation cost for anti-TB drugs can be caused by the price differences of FDC (FixedDose Combination) and non-FDC (for patients who experience side effects due to the use of FDC). Availability of anti-TB drugs is part of the five main strategies of DOTS and the government must guarantee the availability of drugs in sufficient quantities with buffer stock supplies ${ }^{18}$. Based on the data obtained, most patients had received $4 \mathrm{FDC}$ in the initial phase but not all of them continued to 2 FDC in the continuation phase because most of them received the nonFDC in the continuation phase. Besides that, when the stock has run out, the hospital replaces it with trademark drugs.

Variation cost for the drug used to treat the side effects of anti-TB drugs and reduce the symptoms of tuberculosis due to different side effects, the level of side effects, and the different symptoms for every patient. Generally, patients will experience side effects such as red urine, nausea, weakness, vomiting, indigestion (ulcer, stomach ache, constipation), joint pain, dizziness, skin itching, and sleepiness ${ }^{19}$. Complaints of red urine caused by the use of rifampicin do not interfere with the patient's activities, so no additional medication needed to overcome them. As for another effect that interferes with the activity from patients, they tend to get additional medication when consulting a doctor on the control schedule.

Generally, patients receive additional medication in the form of vitamin B6 to treat peripheral neuropathy which is a side effect of isoniazid. Symptoms of flu-like syndrome due to rifampicin are also often felt by patients, for these side effects some patients are given paracetamol or a combination with another drug that available on the market. Side effects such as nausea, vomiting, and other digestive disorders, can be caused by rifampicin, isoniazid, or pyrazinamide $^{20}$. The drugs given will differ depending on the patient's complaints, the drugs that are often given are antacids or antihistamines such as ranitidine. Side effects that arise on the skin, such as pruritus can be caused by rifampicin and isoniazid while dermatitis can be caused by pyrazinamide $^{20}$. Drugs that can be given are oral medications such as antihistamines or topicals such as corticosteroids. Other side effects that can be experienced by patients are impaired liver function due to the use of pyrazinamide and usually, patients will be given Curcuma to reduce SGPT levels ${ }^{21}$. Pyrazinamide can also cause hyperuricemia or joint pain in people who do not suffer gout arthritis and drugs such as allopurinol or NSAIDs was given for this condition ${ }^{20}$. While drugs to reduce the symptoms of tuberculosis such as cough can be given mucolytic, antitussive, or expectorant by following the symptoms of cough that is felt.

Variation cost for sputum examination can be caused by different type and time for sputum examination. In sputum examination, there are two types of examination, namely direct microscopic acid-fast bacillus (AFB 3x) and also RMT (Rapid Molecular Test). Each patient has a variety in terms of examination, where there are patients who only get an AFB 3x smear examination, RMT examination, or even both of examination at one visit. AFB 3x and RMT have different functions, where AFB $3 x$ can function as a diagnosis, determine the potential for transmission, and evaluate treatment evaluation, while RMT is only used to diagnose not to assess treatment evaluation ${ }^{22}$. Sputum examination should be performed by patients at $0,2,5$, and 6 months but based on the patient's medical record, sputum examination is not according to the time set $^{16}$.

Table 4. Average Cost-Utility Ratio (ACUR)

\begin{tabular}{cccc}
\hline Group & Utility & $\begin{array}{c}\text { Total of Treatment Cost } \\
\text { (IDR) }\end{array}$ & $\begin{array}{c}\text { ACUR } \\
\text { (IDR) }\end{array}$ \\
\hline SAT & $0,912^{\mathrm{b}}$ & $5.804 .887,00^{\mathrm{b}}$ & $6.365 .007,67$ \\
$\mathrm{DOT}$ & $0,718^{\mathrm{a}}$ & $5.499 .656,00^{\mathrm{b}}$ & $7.659 .688,02$ \\
$\mathrm{a}=$ mean; $\mathrm{b}=$ median & &
\end{tabular}


Table 5. Incremental Cost-Utility Ratio (ICUR)

\begin{tabular}{cccccc}
\hline Group & $\begin{array}{c}\text { Mean of } \\
\text { Utility (U) }\end{array}$ & $\begin{array}{c}\text { Mean of Incremental } \\
\text { Utility (U) }\end{array}$ & $\begin{array}{c}\text { Median of Costs } \\
\text { (IDR) }\end{array}$ & $\begin{array}{c}\text { Median of Incremental } \\
\text { Cost (IDR) }\end{array}$ & $\begin{array}{c}\text { ICUR } \\
\text { (IDR) }\end{array}$ \\
\hline SAT & 0,912 & & $5.804 .887,00$ & & \\
DOT & 0,718 & 0,194 & $5.499 .656,00$ & $305.231,00$ & $1.573 .355,67$ \\
\hline
\end{tabular}

Variations cost for radiology and anatomical pathology due to the different of examination number and different types of checks. Radiological examination, like chest xray is performed at $0,2,6$ months, or when complications are suspected. However, based on medical records, the chest examination is not always carried out according to the time. Whereas for histopathological examination performed on extrapulmonary TB patients with different actions according to the affected organs and there is no provision regarding the number of examinations that must be carried out.

Variation cost of laboratory costs (other than sputum examination) due to variation in prices for each inspection. Patients carry out additional laboratory examinations to check for side effects due to the use of FDC or to support TB therapy. Additional examinations that enter the procedure for monitoring the treatment of TB patients at the Gatot Soebroto Army Hospital only liver function test (SGPT and SGOT) that can be done at the beginning of treatment, at the second week of treatment, at the end of the intensive period, or if there are suspected side effects. As for other examinations, a test of urea levels, examination of ESR (Erythrocyte Sedimentation Rate), and immunoserology tests for HIV, there is no provision regarding the number of examinations to be carried out and whether it is really necessary or not. This is similar to one of the studies that have been conducted in Indonesia which said need the clinical pathways for outpatient TB patients that guide doctors, patients, and related parties in monitoring TB patient therapy ${ }^{23}$.

Direct nonmedical costs (transportation costs, meal costs, additional costs) and indirect cost showed high variations due to difference needed for every patient. The distance and type of transportation influences variations in transportation costs, there are even patients who do not pay at all (0,00 IDR) because they live in the Gatot Soebroto Army Hospital dormitory. The cost of meals also varies because patients do not always buy food at the hospital and some bring supplies from home. Variation in the additional costs during an illness in TB patients due to the type of expenditure. Some patients need additional costs to buy masks, milk, fruit, vitamins or a wheelchair for bone TB patients who have difficulty walking, IGRA (Interferon Gamma Release Assay) laboratory examinations (not available at Gatot Soebroto Army Hospital), or drug costs that must be incurred due to stocks that are not yet available in the hospital. Indirect cost like opportunity cost also varies because some patients do not work, so the cost will be 0,00 IDR. But for people who have a job, they must close their shop when the control or must get pieces when asking permission to control and even stops from the work.

\subsection{Utility}

In this study, the patient's utility was obtained by filling out the EQ-5D-5L questionnaire which was stated in a range of $0-1$. A value of 0 stated "death" and a value of 1 stated "living perfectly healthy"24. The result of utility value present in Table 3 . The average utility value obtained in the SAT group is 0.912 and the average utility value obtained in the DOT group is 0.718 . However, when the statistical test with Mann-Whitney showed the significance of 0.063 ( $p>0.05$ ), it can be concluded that there is no

Table 6. One Way Sensitivity Analysis

\begin{tabular}{llcc}
\hline \multicolumn{1}{c}{ Strategy } & \multicolumn{1}{c}{ DOT } & SAT & ICUR (IDR) \\
\hline Total Cost & & & \\
0 & $5.499 .656,00$ & $5.804 .887,00$ & $1.573 .355,67$ \\
$-20 \%$ & $4.399 .724,80$ & $4.643 .909,60$ & $2.034 .873,33$ \\
$+20 \%$ & $6.599 .587,20$ & $6.965 .864,40$ & $3.052 .310,00$ \\
Incremental Value of Utility & & & \\
0 & 0.194 & & 0.194 \\
Utility incremental - 20\% & 0.155 & & 0.155 \\
Utility incremental + 20\% & 0.233 & & 0.233 \\
\hline
\end{tabular}


significant difference between the DOT and SAT methods with utility values.

\subsection{Average Cost-Utility Ratio (ACUR)}

The calculation of the average costutility ratio (ACUR) are done by comparing the total cost and utility of treatment in each DOT and SAT group as shown in Table 4. The results obtained from ACUR calculations are 6.365.007,67 IDR for the SAT group and 7.659.688,02 IDR for the DOT group. Based on cost-utility table, the DOT group has a utility value and costs lower than the SAT group, so the alternative position is in category which needs ICUR $^{25}$.

\subsection{Incremental Cost-Utility Ratio (ICUR)}

The calculation of incremental cost-utility ratio (ICUR) is carried out to determine how much additional cost that must patient spend to move from one alternative treatment to another alternative and to determine is it worth between the result of the treatment and the cost that must incur $^{26}$. ICUR calculation can be seen in Table 5 . Based on the ACUR calculation, the incremental value was 1.573.355,67 IDR. This illustrates to move from the SAT method to the DOT method requires an additional fee of 1.573.355,67 IDR. Based on the utility-cost diagram, the DOT and SAT methods go into quadrant I (exchange) and quadrant III (exchange). This causes both methods can be selected according to the available resources, especially funds. The choice of the DOT method produces lower costs with lower utility than the SAT, but when tested statistically there is no significant difference between the utilities in each group. Besides, the absence of a budget limitation (threshold) in this study caused the incremental costs to be incurred by the payer.

\subsection{Sensitivity Analysis}

Sensitivity analysis is used to take the uncertainty aspects of various existing data. Sensitivity analysis carried out in this study is one-way analysis by calculating the effect of using an alternative range for one variable at a time while the other variable is not changed ${ }^{24}$. The analysis was carried out by simulating variations in the medical costs and the incremental value of the utility as seen in Table 6 .
Sensitivity analysis of CUA can be done on costs, discount rates, and HRQoL (healthrelated quality of life). Cost estimates can use ranges of up to $20 \%$, discount rate estimates can use ranges of up to $15 \%$, and HRQoL can use ranges of up to $31 \%{ }^{24}$. According to RNTCP (Revised National Tuberculosis Control Program) data in India, the prevalence of TB population among all of the patients can reach $20 \%$, so the $20 \%$ figure can be used as uncertainty in sensitivity testing ${ }^{27}$. Sensitivity analysis in this study also uses a variation of $20 \%$ considering that Indonesia is the second country with the highest incidence of TB in the world after India.

ICUR calculations with variations in decreases and a total cost increase of $20 \%$ provide ICUR differences of 508.718,00 IDR. In contrast to the variation in total treatment costs, variations in the incremental value of the utility have differences in decreases and increases of $20 \%$. In the incremental increase in utility value, there is an ICUR difference of IDR 423.932,28, whereas for the decrease in incremental utility value there is RIUB difference of IDR $635.897,58$. Based on the results obtained, the variation in the incremental value of utilities is more variable than the total cost of treatment. ICUR results obtained from the sensitivity analysis are considered still acceptable by the payer due to the absence of budget restrictions (threshold).

\section{CONCLUSIONS}

Treatment utility in tuberculosis patients with the DOT method is 0.718 while the SAT method is 0.912 . The total cost of treatment is seen from the societal perspective, which includes direct medical costs, direct nonmedical costs, and indirect costs. The cost required for tuberculosis patients with the DOT method is 5.499,656.00 IDR while the SAT method is 5.804.887,00 IDR. The choice of the DOT produces lower costs with lower utility than the SAT which need an additional fee of 1.573.355,67 IDR, but when tested statistically there is no significant difference between the utilities in each group. The additional fee still can be accepted because there is no threshold used in this study. This causes both methods can be selected according to the available resources, especially funds. 


\section{LIMITATIONS}

This study was an observational study with a cross-sectional method. The utility value used to determine the quality of life also had a high level of subjectivity due to differences in perceptions of each patient. Besides, the difficult to find samples with DOT from the family member can affect the result of statistical calculation due to a little number of samples.

\section{ACKNOWLEDGMENTS}

This work was supported by Hibah Publikasi Internasional Terindeks Untuk Tugas Akhir Mahasiswa UI (PITTA) 2018 by Universitas Indonesia. We thank PITTA 2018 for providing the fund that used in the study.

\section{Conflict of interest}

No possible conflict of interest has been identified relevant to this article

\section{Funding}

This work was funded by Universitas Indonesia

\section{Ethical approval}

This study was ethically approved by the Health Research Ethics Committee, Faculty of Medicine, Universitas Indonesia - Cipto Mangunkusumo Hospital (Protocol Number: 18-03-0221)

\section{Article info:}

Received March 17, 2019

Received in revised form August 9, 2019

Accepted September 17, 2019

\section{REFERENCES}

1. WHO. Global Tuberculosis Report 2017 [ Internet]. WHO. 2017. p. 1-262.

2. Kementerian Kesehatan Republik Indonesia Ditjen PP dan PL. Pedoman Nasional Pengendalian Tuberkulosis (National Guidelines for Tuberculosis Management) [Internet]. Kementerian Kesehatan RI. 2014. p. 38. Available from: http://www.tbindonesia. or.id/opendir /Buku/bpn_p-tb_2014.pdf.

3. WHO SEARO. What is DOTS (directly observed treatment, short course) [Internet]. WHO SEARO. 2018. Available from: http://www. searo. who. int/tb/topics/ what dots/en/.

4. Pare AL, Amiruddin R, Leida I. Hubungan antara pekerjaan, pmo, pelayanan kesehatan, dukungan keluarga dan diskriminasi dengan perilaku berobat pasien tb paru (Relationship between work, DOT, health services, family support and discrimination with the treatment behavior of pulmonary tuberculosis patients). 2010:1-13.

5. Kastien-Hilka T, Abulfathi A, Rosenkranz B, Bennett B, Schwenkglenks M, Sinanovic E. Health-related quality of life and its association with medication adherence in active pulmonary tuberculosis- a systematic review of global literature with focus on South Africa. Health Qual Life Out. 2016 Dec;14(1):42.

6. Oktavia D, Perwitasari DA, Supadmi W. Qualityadjusted life years (QALYs) of tuberculosis patients in the intensive and continuous phase in a private hospital of Yogyakarta, Indonesia. J Pharm Biomed Sci. 2016;6(1):22-5.

7. Kruijshaar ME, Lipman M, Essink-Bot ML, Lozewicz S, Creer D, Dart S, et al. Health status of UK patients with active tuberculosis. Int $\mathrm{J}$ Tuberc Lung Dis. 2010;14(3):296-302.

8. Malik M, Nasir R, Hussain A. Health related quality of life among tb patients: Question mark on performance of TB DOTS in Pakistan. J Trop Med. 2018;2018:1-7.

9. Karumbi J, Garner P. Directly observed therapy for treating tuberculosis. Cochrane Database Syst Rev. 2015 (5):CD003343

10. Collins D, Hafidz F, Mustikawati D. The economic burden of tuberculosis in Indonesia. Int J Tuberc Lung Dis. 2017 Sep;21(9):1041-8.

11. Steffen R, Menzies D, Oxlade O, Pinto M, de Castro AZ, Monteiro P, et al. Patients' costs and cost-effectiveness of tuberculosis treatment in DOTS and non- DOTS facilities in Rio de Janeiro, Brazil. PLoS One. 2010. 5(11):e14014.

12. Hunchangsith $P$, Barendregt JJ, Vos T, Bertram M. Cost- effectiveness of various tuberculosis control strategies in Thailand. Value Health. 2012;15( 1 Suppl.):S50-5.

13. Putra DP, Bustamam N, Chairani A. Hubungan Berhenti Merokok dengan Tingkat Keparahan Penyakit Paru Obstruktif Kronik Berdasarkan GOLD 2013. J Respir Indo. 2013;36(1):20-7.

14. EuroQol. EQ-5D-5L- userguide 2015 [Internet]. EuroQol. 2015. Available from: https://euroqol. org/wp-content/ uploads/2016/09/EQ-5D-5L_UserGuide_2015.pdf.

15. Purba FD, Hunfeld JAM, Iskandarsyah A, Fitriana TS, Sadarjoen SS, Ramos-Goñi JM, et al. The Indonesian EQ- 5D- 5L value set. Pharmacoeconomics. 2017;35(11):1153-65.

16. Menteri Kesehatan RI. Peraturan Menteri Kesehatan Republik Indonesia Nomor 28 Tahun 2014 tentang Pedoman Pelaksanaan Program Jaminan Kesehatan Nasional (Guidelines for National Health Insurance Program Implementation). Kementrian Kesehatan RI. 2014;1-48.

17. Amiruddin R, Abdullah $\mathrm{T}$, Kesehatan D, Bone $\mathrm{K}$. Faktor- faktor Yang Berhubungan Dengan Kejadian Tuberkulosis Paru Pada Masyarakat Di Propinsi Sulawesi Selatan 2007 (Factors Related to the Incidence of Pulmonary Tuberculosis in South Sulawesi Province 2007). 2010;6(4).

18. Dirjen P2\&PL Kementerian Kesehatan RI. Terobosan Menuju Akses Universal, Strategi Nasional Pengendalian TB di Indonesia 2010- 2014 (Breakthroughs Towards Universal Access, National Strategy for TB Management in Indonesia 2010-2014) [Internet]. Kementerian Kesehatan RI. 2011;1-80. Available from: http://www. searo. who. int/indonesia/ topics/tb/stranas_tb-2010-2014.pdf.

19. Farhanisa, Untari EK, Nansy E. Kejadian Efek Samping Obat Anti Tuberkulosis (OAT) Kategori 1 Pada Pasien TB Paru Di Unit Pengobatan Penyakit Paru-Paru (UP4) Provinsi Kalimantan Barat (Occurrence of Category 1 Anti-Tuberculosis Drugs (ATD) Side Effects in Pulmonary TB Patients at Lung Disease Treatment Unit of West Kalimantan Province). 2014;2337(2):1-2. 
20. Arbex MA, Varella MDCL, Siqueira HR De, Mello FAF De. Antituberculosis drugs: Drug interactions, adverse effects, and use in special situations. Part 1: First-line drugs. J Bras Pneumol. 2010;36(6):626-40.

21. Rachmawati E. Efek Pemberian Sediaan Poliherbal Kombinasi Meniran, Temulawak, dan Kunyit dalam Mencegah Peningkatan SGPT pada Pasien Pengguna Obat Anti Tuberkulosis (The effectiveness of Phyllanthus niruri, Curcuma xanthorrhiza, and Curcuma longa combination in preventing the elevation of ALT levels during patients TB treatment). Universitas Gadjah Mada; 2014.

22. Kementrian Kesehatan Republik Indonesia. Peraturan Menteri Kesehatan Republik Indonesia No. 67 Tahun 2016 Tentang Penanggulangan Tuberkulosis (Tuberculosis Management). 2016;24.

23. Sari ID, Herman MJ, Susyanty AL, Su' udi A. Analisis Biaya Tuberkulosis Paru Kategori Satu Pasien Dewasa di Rumah Sakit di DKI Jakarta Cost Analysis of
Category One Pulmonary Tuberculosis Treatment in Adult Patient in Hospital in DKI Jakarta(Cost Analysis of Category One Pulmonary Tuberculosis Treatment in Adult Patients in Hospital in DKI Jakarta). 2017;8(1):44-54.

24. Rascati KL. Essentials of pharmacoeconomics. 2nd ed. Lippincott Williams \& Wilkins; 2014.

25. Kementerian Kesehatan Republik Indonesia. Pedoman Penerapan Kajian Farmakoekonomi (Guidelines for Application of Pharmacoeconomic Studies). Kementerian Kesehatan Republik Indonesia. 2013. 14 p.

26. Trask LS. Pharmacotherapy: A pathophysiologic approach. In: 8th ed. New York: The McGraw-Hill Companies, Inc.; 2011.

27. Kelly V, Sagili KD, Satyanarayana S, Reza LW, Chadha SS, Wilson NC. Cost- utility analysis of LED fluorescence microscopy in the diagnosis of pulmonary tuberculosis in Indian settings. Int $\mathbf{J}$ Tuberc Lung Dis. 2015;19(6):696-701. 